II. RECENZJE I OMÓWIENIA

DOI: $10.17951 /$ et.2015.27.244

\title{
Damian Gocół
}

\section{RELACJE KAZACHSTAŃSKICH POLAKÓW Z PERSPEKTYWY HISTORII MÓWIONEJ}

Wiktoria Kudela-Świątek, Odpamiętane. O historii mówionej na przykładzie narracji kazachstańskich Polaków o represjach na tle narodowościowym i religijnym, Kraków: TAiWPN „Universitas”, 2013, 376 s.

Historia mówiona stała się $\mathrm{w}$ ciągu ostatnich dwudziestu lat niezwykle popularnym kierunkiem w nauce. Omawiana monografia zawiera szczegółowy przegląd dotychczasowych publikacji związanych z tematyką oral history: autorka przedstawiła genezę nurtu, jego rozwój w różnych dziedzinach działalności ludzkiej oraz metodologię badań ustnych narracji o historii. Książkę wyróżnia konsekwentnie antropologiczne podejście do badanych narracji.

Metody stosowane $\mathrm{w}$ analizie ustnych opowieści o historii najczęściej są dzielone na typowe dla historii oraz właściwe innym naukom humanistycznym. W pierwszym wypadku badacz skupia się na treści opowiadania. Drugie podejście, nazywane socjologicznym bądź antropologicznym, opiera się na przekonaniu, że forma narracji jest równie ważna jak jej treść i może być źródłem wielu informacji. Autorka książki jest zdania, że tradycyjne metody badań historycznych nie są już wystarczające dla badań oral history. Podkreśla wagę kontaktu z żywym słowem i badania podmiotowości narratorów oraz osadzenie narracji w kontekście kulturowym, językowym i społecznym. Z tych powodów, zdaniem badaczki, przekaz ustny jest źródłem w pełnym znaczeniu tego słowa, a nie jedynie uzupełnieniem dokumentacji pisanej. Autorka podejmuje się zatem redefinicji celu badań historycznych. Dla historyka oralisty nie jest nim rekonstrukcja przeszłych wydarzeń przeszłość nie jest nam bowiem bezpośrednio dostępna, badamy jedynie narracje na jej temat; historyk opisuje więc tylko różne punkty widzenia. Tym samym do nauk historycznych przenika relatywizm - pojęcie „prawdy historycznej” staje się dyskusyjne.

Podkreślając interdyscyplinarność oral history, Kudela-Świątek szuka inspiracji zarówno w historii, jak i w innych naukach - socjologii, psychologii, etnolingwistyce. Wiele uwagi poświęca sytuacji komunikacyjnej, która kształtuje się podczas zbierania materiału. Analizuje wpływ różnych czynników na kształt opowiadania. Skłania się ku metodzie wywiadu otwartego jako optymalnego sposobu gromadzenia narracji. 
Materiałową podstawą przeprowadzonych w książce analiz jest obszerny zbiór narracji ustnych uzyskanych od mieszkańców Kazachstanu, którzy mają polskie korzenie. W jego skład wchodzi 88 nagrań (w tym 37 ze zbiorów Ośrodka „Karta”). Ponieważ zbiór jest zbyt obszerny, by w całości umieścić go w książce, fragmenty relacji pojawiają się jedynie w ramach analiz (rozpatrywane fragmenty zostały również umieszczone na płycie CD). Badane narracje dotyczą życia i tożsamości tzw. kazachstańskich Polaków.

Autorka podkreśla potrzebę zmiany obrazu polskiej społeczności na Wschodzie. Może się to odbyć również poprzez zastosowanie metod historii mówionej. Obraz kazachstańskich Polaków byłby wówczas rekonstruowany na podstawie ich własnych opowiadań, a nie tylko źródeł pisanych, jak pamiętniki czy książki o przesiedleniach. Obecnie zazwyczaj grupa ta jest przedstawiana jako zbiorowość starszych osób, silnie związanych z kulturą dawnych Kresów. Z wypowiedzi samych kazachstańskich Polaków wyłania się obraz odmienny. Ich związki z Polską w ciągu wielu lat od deportacji znacznie osłabły, nie wszyscy potrafią się posługiwać językiem przodków. Co więcej, wielu kazachstańskich Polaków czuje się mocniej związanych z Ukrainą jako miejscem swojego urodzenia niż z Polską. Wpływ na ich tożsamość miały także wieloletnia komunistyczna propaganda i trudne warunki życia w kołchozie. Świadomość powiązania z Polską znacznie słabnie, szczególnie $\mathrm{w}$ młodszym pokoleniu.

Opisując to zjawisko, autorka wprowadza termin postpamięć; jest to pamięć przekazywana kolejnym generacjom. Opowiadania o deportacjach i dawnej ojczyźnie coraz słabiej wpływają na kształtowanie tożsamości najmłodszego pokolenia Polaków w Kazachstanie. Nie można już mówić o znajomości polskiej historii czy kultury jako o czynnikach integrujących społeczność, gdyż mają one raczej niewielki wpływ na jej życie. Ważniejszym czynnikiem spajającym grupę jest przynależność do Kościoła katolickiego, który pełni często funkcję edukacyjną i organizuje doraźną pomoc. Tożsamość kazachstańskich Polaków najsilniej kształtuje fakt ich represjonowania, stale obecny w badanych narracjach. Właśnie wątek represji jest dokładniej analizowany przez badaczkę.

Dla potrzeb analizy zebranego materiału Kudela-Świątek korzysta z różnych metod badawczych. Ponieważ skupia się na rekonstrukcji tożsamości narratorów, czerpie głównie z narracyjnego nurtu psychologii. Sięgając do prac Jerzego Trzebińskiego, przywołuje np. podział narracji na opowieści o charakterze proaktywnym i defensywnym. Rozróżnienie to jako kryterium podziału przyjmuje postawę jednostki wobec wydarzeń, o których ona opowiada - może odgrywać w nich rolę agensa bądź biernie poddawać się losowi. Kudela-Świątek uznała, że podział ten nie wystarcza do uporządkowania zebranych narracji, dlatego stworzyła własną typologię. Wyróżnia narracje performatywne, analityczne i symboliczne. Performatywne mają charakter opowieści biograficznych, uzupełnianych własnymi ocenami, emocjami itp., a główną rolę odgrywa w nich opowiadanie o wydarzeniach. Typ analityczny wyróżnia się motywem przewodnim, wokół którego koncentruje się narracja. Opowieści symboliczne eksponują jakąś pamiętną zmianę w życiu narratora, która nadaje egzystencji sens. Propozycja autorki budzi jednakże wątpliwości. Nie zostało w niej wskazane jedno kryterium podziału, a wyróżnione klasy 
nie są rozłączne. Kudela-Świątek nie wyjaśniła również, na czym miałaby polegać „performatywność" narracji. Wykorzystanie ogólnych ustaleń psychologii jest natomiast dobrą decyzją - badania tożsamościowe nie powinny być prowadzone bez odpowiednich podstaw teoretycznych.

Warto podkreślić, że w analizie narracji kazachstańskich Polaków autorka przywiązuje wielką wagę do języka. Podkreśla specyfikę przekazu ustnego i zwraca uwagę na bogactwo gatunkowe narracji mówionych (dostrzega w nich podobieństwo m.in. do rosyjskiego skazu). Zauważa również występowanie pewnych utrwalonych sposobów opowiadania o represjach. Jako podstawę swoich analiz przyjmuje koncepcję językowego obrazu świata w ujęciu Jerzego Bartmińskiego.

Dla badaczki szczególnie istotny jest sposób przedstawienia ,zniewolenia" w badanych narracjach. Punktem wyjścia analiz są słownikowe definicje słów używanych na określenie sytuacji zniewolenia. Ciekawym aspektem badanych narracji jest wpływ różnych tradycji językowych. Większość relacji została przekazana w języku rosyjskim, ponieważ narratorzy nie potrafili biegle posługiwać się polskim lub nie znali tego języka. Natomiast narracje polskojęzyczne często były uzupełniane rusycyzmami. Dlatego w analizowanych materiałach nakładają się na siebie dwie kultury i krzyżują się dwa obrazy świata - co odzwierciedla się w mentalności narratorów, którzy nie czują pełnej przynależności do żadnego obszaru kulturowego.

Kudela-Świątek uważa, że najwierniejszy nawet zapis nie odda specyfiki narracji oralnej - i niewątpliwie ma rację. Transkrypcja zawsze zależna jest od interpretacji badacza, który musi opisać subkod kinetyczny, prozodyczny czy proksemiczny. Aby uniknąć subiektywizmu, autorka umieściła nagrania wszystkich fragmentów cytowanych w książce na płycie CD. Szukając odpowiedniej formy oddania w piśmie tekstów mówionych, zastosowała transkrypcję pozbawioną wielkich liter i znaków interpunkcyjnych. Efektem jest zapis, w którym nie widać granicy między zdaniami; pauzy oznaczone są jedynie ukośnikami. Zamiast stać się bliższym ustnemu oryginałowi, przeciwnie - otrzymał nieczytelną formę, która nie oddaje specyfiki żywej mowy w tak dobry sposób, jak transkrypcja półfonetyczna (szczególnie trudne jest odczytanie transkrypcji rosyjskojęzycznych). 